\title{
The Outcome of Hemolytic Disease of the Fetus and Newborn Caused by Anti-Rh17 Antibody: Analysis of Three Cases and Review of the Literature
}

\author{
Slavica Dajak ${ }^{a}$ Nina Ipavec ${ }^{a}$ Mia Cuk $^{a}$ Branka Golubic Cepulic ${ }^{b}$ \\ Jela Mratinovic-Mikulandra ${ }^{a}$ Josipa Milardovic ${ }^{a}$ Vedran Stefanovic ${ }^{c}$ \\ ${ }^{a}$ Department of Transfusion Medicine, Split University Hospital Center Split, Split, Croatia; ${ }^{b}$ Department of \\ Transfusion Medicine and Transplantation Biology, University Hospital Center Zagreb, Zagreb, Croatia; ' $D e p a r t m e n t$ \\ of Obstetrics and Gynecology, Fetomaternal Medical Center, Helsinki University Hospital and University of Helsinki, \\ Helsinki, Finland
}

Keywords

Anti-Rh17 · Hemolytic disease of the fetus and newborn · D-- phenotype

\begin{abstract}
Background: Anti-Rh17 is a rare red blood cell (RBC) antibody to high-frequency antigens that may cause severe hemolytic disease of the fetus and newborn (HDFN). Despite the rarity of HDFN caused by Anti-Rh17, this antibody was reported in many different populations. Emergency transfusions, especially exchange transfusions, present a huge problem if no compatible RBCs of phenotype D-- are available. Methods: Here we report obstetrical histories of three women and describe their pregnancies complicated by anti-Rh17 antibodies. We summarized published cases of pregnancies complicated by anti-Rh17 and reviewed transfusion treatment and outcomes. Additionally, a simplified flowchart for the management of such pregnancies is proposed. Results: Four pregnancies were affected by severe HDFN, and three of them ended with perinatal death. In the fourth case, the baby was born hydropic and icteric and the condition was rapidly deteriorating. Emergency exchange transfusion was performed with incompatible O-negative RBC units in AB-negative plasma. The baby was discharged on the 14th day in good health. In the available literature, 15 women and 22 pregnancies were reported, 20 of them developed severe HDFN. Ac-
\end{abstract}

cording to the data, intrauterine transfusion for treatment of HDFN was the most common form of treatment with the donation of the mother's blood. Different options for exchange transfusion were described, including incompatible RBCs. Conclusion: In more than $90 \%$ of described pregnancies of HDFN caused by anti-Rh17 antibody, transfusion treatment was required. Therefore, RBC from D-- phenotype has to be available. According to published data, in emergent circumstances when maternal and blood from donor with phenotype D-- is not available, incompatible exchange transfusion is a better choice than delaying transfusion when it is necessary. It is of essential importance that pregnancies with high risk of HDFN due to anti-Rh17 are managed by a multidisciplinary team (transfusion medicine specialist, obstetrician, neonatologist) in a highly specialized tertiary institution.

(c) 2019 S. Karger AG, Basel

\section{Introduction}

The Rh blood group is one of the most polymorphic blood group systems in humans. It attracts particular attention due to its immunogenicity in both transfusion medicine and pregnancy. Two highly homologous genes on chromosome 1 encode the polypeptides that express the Rh antigens. RHD gene determines the presence of membrane protein that confers $\mathrm{D}$ activity. The other 
gene, $R H C E$, determines the $\mathrm{C}, \mathrm{c}, \mathrm{E}$, e antigens. The products of both RHD and RHCE are proteins of 417 amino acids that transverse the red cell membrane 12 times [1]. The rare haplotype D--, first described in 1950, is characterized by the complete absence of C, c, E, e antigens and the elevated expression of $\mathrm{D}$ on the surface of red blood cells (RBC) [2]. Molecular basis for D-- is thought to be derived from a homologous deletion of the RHCE genes and is passed on to descendants in a Mendelian ratio [3].

Despite the rarity of phenotype D--, this phenotype has been identified in many different populations: white Americans and Europeans, Native Americans, African Americans, Japanese, Chinese, Koreans, Asian Indians, and Iranians. Almost all D-- individuals have been ascertained through the presence of specific antibodies in their serum anti-Rh17 [4].

Hemolytic disease of the fetus and newborn (HDFN) is caused by RBC antibodies of IgG class that are actively transported across the placenta and cause destruction of fetal RBCs. The risk of severe HDFN depends on several factors, including IgG subclass, specificity, titer of antibodies, and the level of expression of the involved antigen on the fetal RBCs [1]. Anti-Rh17 antibodies have been reported to cause mostly very severe HDFN, but in a few cases HDFN was mild [1, 4].

Severe HDFN may be managed by intrauterine transfusion (IUT), exchange transfusion (ET), or top-up transfusions. It is particularly difficult to find matching blood because only 1:100,000 people are Rh17 negative [4]. That is why in most of these cases, the blood donor is the child's mother. Close relatives from the mother's side (like a mother's sibling) can also serve as donors if they have D-- phenotype. Matched blood can be obtained from blood banks of rare blood groups, which is a reasonable alternative if the transfusion treatment is planned well in advance.

Emergency transfusions and ETs present a huge problem if no compatible blood is available. Any delay in transfusion treatment of severe HDFN carries a great risk for the fetus and child. That is why some cases of HDFN were treated by incompatible blood, mostly maternal ABO-mismatched blood.

Here we report obstetrical histories of three women with pregnancies complicated by anti-Rh17 antibodies. A literature review of all published and well-documented cases of anti-Rh17 pregnancies and analyzed transfusion treatment of HDFN and outcomes was done and a simplified flowchart for the management of such pregnancies is proposed.

\section{Results}

\section{Case Reports}

During 18 years, we have identified three pregnant women with anti-Rh17 referred to the Department of
Transfusion Medicine, University Hospital of Split, Croatia. Although these women are not blood related (selfreported), they all originate from the same village of 2,000 inhabitants in Split-Dalmatian County.

\section{Case 1}

First Pregnancy

A 27-year-old Caucasian (gravida 1, abortion 0, no previous transfusion) was referred at the 12th week of gestation for routine antenatal transfusion testing. Her blood group was $\mathrm{A}, \mathrm{RhD}+$, and antibody screening was negative. At admission, apart from the mild anemia treated by iron supplements, she had no other medical problems. During pregnancy, she felt weak and has developed severe anemia, despite the fact that she was taking iron pills. Blood count in the 19th week of pregnancy revealed that hemoglobin level was $7.2 \mathrm{~g} / \mathrm{dL}$, and she received one unit of packed RBCs in the 20th gestational week. Antibody screening and cross match prior to transfusion were negative. In the 34th week of gestation, she was admitted due to the absence of fetal movements and the stillbirth was revealed by ultrasound examination. Autopsy results of the fetus reported signs of severe organ malformation, aspiration of amniotic fluid in lungs, predomination of immature blood cells in the blood vessels, and hypercellularity of bone marrow corresponding to HDFN as a cause of stillbirth. Her RBC antibody screening was positive and antibody identification revealed agglutination with all cells. These results were suggestive for alloantibody against a high-prevalence antigen. Maternal Rh phenotype was D+, C-, c-, E-, e-, K-, and anti-Rh17 antibody was suspected. Blood sample was sent to Blood Group Reference Laboratories, Bristol (IBGRL) UK, where antiRh17 was confirmed with no underlying antibodies.

\section{Second Pregnancy}

One year after the first pregnancy, the subsequent pregnancy ended in spontaneous abortion at the 10th gestational week.

\section{Third Pregnancy}

One year after the second pregnancy, the antibody screening at the 12th gestational week was positive with anti-Rh17 titer $>1: 2,048$. The follow-up of anti-Rh17 titer and this pregnancy were managed at University Hospital Center Zagreb, which is a national center for highrisk pregnancies. Plasmapheresis was performed in order to alleviate the immune response and titer of anti-Rh17 antibodies. Fetal anemia was treated by two IUTs at the 25th and 27th week of gestation with washed and irradiated maternal RBC. Regardless of the treatment, intrauterine death of the fetus occurred at the 28th week of gestation. 
Table 1. Outcome and transfusion therapy of HDFN caused by anti-Rh17 alloimmunization

\begin{tabular}{llllll}
\hline Case & Origin of immunization & $\begin{array}{l}\text { Order of } \\
\text { pregnancies }\end{array}$ & HDFN and outcome & $\begin{array}{c}\text { Transfusion } \\
\text { therapy of } \\
\text { HDFN }\end{array}$ & $\begin{array}{c}\text { Source of RBC for } \\
\text { fetal and neonatal } \\
\text { transfusion }\end{array}$ \\
\hline 1 & $\begin{array}{l}\text { Pregnancy or transfusion; } \\
\text { transfusion of RBC at 20th week } \\
\text { of gestation during first pregnancy } \\
\text { due to maternal anemia }\end{array}$ & First & Second & Miscarriage at 10th week & No \\
\cline { 2 - 6 } & Third & Stillbirth in 28th week & 2 IUT & Maternal RBC \\
\hline 2 & Previous pregnancies & Fourth & $\begin{array}{l}\text { Premature labor 28th week } \\
\text { and neonatal death 3 weeks }\end{array}$ & $\begin{array}{l}\text { Compatible fresh } \\
\text { donor's RBC }\end{array}$ \\
\hline 3 & Previous pregnancy & Second & $\begin{array}{l}\text { Delivery at 37th week; after therapy } \\
\text { the infant is alive and in good health }\end{array}$ & 1 ET, 2 TUT & $\begin{array}{l}\text { Incompatible O } \\
\text { RhD-negative RBC }\end{array}$ \\
\cline { 2 - 6 } & Third & Stillbirth at 6th month of pregnancy & No & No \\
\cline { 2 - 6 } & Forth & Stillbirth at 5th month of pregnancy & No & \\
\hline
\end{tabular}

IUT, intrauterine transfusion; ET, exchange transfusion; TUT, top-up transfusion.

Case 2

A 37-year-old (gravida 4, abortion 1, 2 children, no previous transfusion). Her first pregnancy resulted in miscarriage, and her subsequent two pregnancies were uneventful. Her blood group was $\mathrm{B} \mathrm{RhD}+$ and antibody screening tests in the first trimester of the second and third pregnancies were negative. During her fourth pregnancy, she was referred at the 16th week of gestation for routine antenatal immunohematology testing and antibody screening, which turned out to be positive. Antibody identification revealed agglutination with all cells. Since her phenotype was D--, anti-Rh17 antibody was suspected. Blood samples were sent to Blood Group Reference Laboratories, Bristol (IBGRL), UK, where only anti-Rh17 antibodies were confirmed. The initial titer of anti-Rh17 was 1:512 in the beginning of pregnancy and at the 26th week of pregnancy it was $>1: 2,048$. Caesarean section was performed at the 28 th week of pregnancy. A child was born with severe HDFN, blood group was B+ and direct antiglobulin test was strongly positive. ET was done on the second postnatal day with compatible $\mathrm{B}+$, $\mathrm{D}-\mathrm{RBC}$, after which two top-up transfusions of $\mathrm{B} \mathrm{RhD+ \text {, }}$ D-- compatible RBC and two transfusions of platelets concentrate were administered. However, the infant died 3 weeks later.

\section{Case 3}

A 34-year-old woman (gravida 2, abortion 0, 1 child, no previous transfusion). Her blood group was A RhD+ and antibody screening in the first pregnancy was negative. During her second pregnancy, she was not referred for the routine antenatal immunohematology testing. She delivered a hydropic and icteric infant at the 37 th week of gestation. Direct antiglobulin test of the newborn was strongly positive, and blood group was $\mathrm{A} \mathrm{RhD+,} \mathrm{with} \mathrm{C}+$, c-, E-, e+, K-. Maternal antibody screening was positive and antibody identification revealed agglutination with all cells. Crossmatch of the mother's serum with all donor cells was strongly positive. The newborn's condition was rapidly deteriorating, so ET was done with incompatible $\mathrm{RBC}, \mathrm{O}$-negative $\mathrm{RBC}$ in $\mathrm{AB}$-negative plasma. The child received two top-up transfusions of $\mathrm{O}$-negative $\mathrm{RBC}$ within 14 days and was discharged the 14th day in good condition. Later on, maternal blood samples were sent to Blood Group Reference Laboratories, Bristol, UK, where anti-Rh17 antibodies without other underlying antibodies were confirmed.

This woman had two subsequent pregnancies and both ended up with intrauterine death; the third pregnancy in the 6th, and the forth in the 5th month of gestation. Data from these cases are summarized and displayed in Table 1.

\section{Published Case Reports of HDFN Caused by \\ Anti-RH17}

Published case reports of HDFN caused by anti-Rh17 are shown in Table 2.

\section{Discussion}

Anti-Rh17 antibodies usually cause very severe HDFN, with fatal outcome. Searching the currently available literature on HDFN caused by anti-Rh17 identified 15 women and 22 pregnancies. Severe HDFN occurred in 20 pregnancies, out of which 7 were fatal and only 2 cases presented with moderate HDFN [5-18]. We described management of 4 pregnancies in 3 women with HDFN due to anti-Rh17 alloimmunization, of which 3 did not result in live birth. Therefore, we confirm the previous 
Table 2. Published case reports of HDFN caused by anti-Rh17 alloimmunization: outcome and transfusion therapy of HDFN

\begin{tabular}{|c|c|c|c|c|c|}
\hline Case & $\begin{array}{l}\text { Authors [reference], } \\
\text { year of publication }\end{array}$ & $\begin{array}{l}\text { Order of } \\
\text { pregnancies }\end{array}$ & HDFN and outcome & $\begin{array}{l}\text { Transfusion } \\
\text { therapy and } \\
\text { other manage- } \\
\text { ment of HDFN }\end{array}$ & $\begin{array}{l}\text { Source of RBC for } \\
\text { fetal and neonatal } \\
\text { transfusion }\end{array}$ \\
\hline \multirow[t]{2}{*}{1} & \multirow[t]{2}{*}{$\begin{array}{l}\text { De Torregrosa et al. } \\
\text { [5], } 1961\end{array}$} & First & $\begin{array}{l}\text { Neonatal jaundice at age } 24 \mathrm{~h} \text {, at the fourth day clinical } \\
\text { presentation of neonatal generalized edema and poor } \\
\text { general condition; ET was late and neonate died toward } \\
\text { the end of the procedure }\end{array}$ & $\begin{array}{l}1 \text { ET after } \\
4 \text { days }\end{array}$ & Maternal RBCs \\
\hline & & Second & Stillborn fetus in 7 th month of pregnancy & & \\
\hline \multirow[t]{2}{*}{2} & \multirow{2}{*}{$\begin{array}{l}\text { Badakere and Bhatia } \\
{[6], 1973}\end{array}$} & Fifth & Neonatal death within the first $24 \mathrm{~h}$ & $1 \mathrm{ET}(180 \mathrm{~mL})$ & Maternal RBCs \\
\hline & & Sixth & Neonatal death within the first $24 \mathrm{~h}$ & $1 \mathrm{ET}(180 \mathrm{~mL})$ & Maternal RBCs \\
\hline 3 & Diao et al. [7], 1990 & Third & $\begin{array}{l}\text { CS at 36th week of pregnancy; severe anemia and } \\
\text { hyperbilirubinemia; after therapy baby is alive and in } \\
\text { good health }\end{array}$ & $1 \mathrm{ET}, 1 \mathrm{TUT}$ & $\begin{array}{l}\text { Incompatible } \\
\text { RBCs phenotype } \\
\text { ccDEE }\end{array}$ \\
\hline 4 & $\begin{array}{l}\text { Mertens et al. [8], } \\
1997\end{array}$ & Second & $\begin{array}{l}\text { CS in 39th week of pregnancy, severe neonatal anemia } \\
\text { and hyperbilirubinemia; after therapy the infant is alive } \\
\text { and in good health }\end{array}$ & $1 \mathrm{ET}$ & $\begin{array}{l}\text { Compatible } \\
\text { thawed RBC } \\
\text { (Bank of Frozen } \\
\text { Blood) }\end{array}$ \\
\hline 5 & Han et al. [9], 1997 & Third & $\begin{array}{l}\mathrm{CS} \text {, severe anemia }(\mathrm{Hb} 3.5 \mathrm{~g} / \mathrm{dL}) \text { and fetal hydrops; } \\
\text { neonatal death due to generalized hydrops }\end{array}$ & $1 \mathrm{ET}, 1 \mathrm{TUT}$ & $\begin{array}{l}\text { Incompatible } \\
\text { RBCs (ET), } \\
\text { maternal RBCs } \\
\text { (TUT) }\end{array}$ \\
\hline \multirow[t]{2}{*}{6} & \multirow{2}{*}{$\begin{array}{l}\text { Whang et al. [10], } \\
2000\end{array}$} & Third & Baby died because of HDFN & & \\
\hline & & Fourth & $\begin{array}{l}\text { CS in 34th week; three plasma exchange therapies } \\
\text { during pregnancy before IUTs; after therapy the infant } \\
\text { is alive and in good health }\end{array}$ & 3 IUT, 2 ET & $\begin{array}{l}\text { Maternal RBCs } \\
\text { (IUT), compatible } \\
\text { RBCs from } \\
\text { relatives (ET) }\end{array}$ \\
\hline 7 & $\begin{array}{l}\text { Lenkiewicz and } \\
\text { Zupanska [11], } 2000\end{array}$ & Second & Moderate HDFN & $\begin{array}{l}\text { Phototherapy } \\
\text { only }\end{array}$ & \\
\hline 8 & $\begin{array}{l}\text { Deitenbeck et al. } \\
{[12], 2002}\end{array}$ & Fifth & CS in 34th week & $\begin{array}{l}2 \text { IUT, } 1 \text { ET, } \\
1 \text { TUT, IVIG }\end{array}$ & $\begin{array}{l}\text { Maternal RBCs } \\
\text { frozen before } \\
\text { pregnancy }\end{array}$ \\
\hline 9 & $\begin{array}{l}\text { Brumit et al. [13], } \\
2002\end{array}$ & Second & Moderate HDFN & $\begin{array}{l}\text { Phototherapy } \\
\text { only }\end{array}$ & \\
\hline 10 & Aref et al. [14], 2002 & Second & $\begin{array}{l}\text { Severe anemia }(\mathrm{Hb} 6 \mathrm{~g} / \mathrm{dL}) \text { and fetal hydrops, CS at } 33 \mathrm{rd} \\
\text { week of pregnancy, resolution of neonatal hydrops after } \\
\text { therapy; correction of duodenal atresia }\end{array}$ & $\begin{array}{l}2 \text { ET, IVIG, } \\
\text { erythropoietin }\end{array}$ & $\begin{array}{l}\text { Compatible } \\
\text { thawed RBCs }\end{array}$ \\
\hline \multirow[t]{2}{*}{11} & \multirow[t]{2}{*}{$\begin{array}{l}\text { Denomme et al. } \\
{[15], 2004}\end{array}$} & Second & $\begin{array}{l}\text { Delivery at 30th week of pregnancy after premature } \\
\text { rupture of membranes; severe anemia }(\mathrm{Hb} 6 \mathrm{~g} / \mathrm{dL}) \text { and } \\
\text { hyperbilirubinemia; baby was discharged from hospital } \\
\text { after } 1 \mathrm{ET}\end{array}$ & $1 \mathrm{ET}$ & $\begin{array}{l}\text { Incompatible O } \\
\text { RhD-negative } \\
\text { RBCs }\end{array}$ \\
\hline & & Third & $\begin{array}{l}\text { CS due to fetal distress after induction of labor at 38th } \\
\text { week of pregnancy; phototherapy was initiated at birth } \\
\text { but was discontinued due to low bilirubin levels; } \\
\text { follow-up } 2 \text { weeks later showed evidence of mild anemia } \\
\text { that did not require transfusion }\end{array}$ & $\begin{array}{l}7 \text { IUT, } \\
\text { phototherapy }\end{array}$ & $\begin{array}{l}\text { Maternal ABO } \\
\text { incompatible } \\
\text { RBCs }\end{array}$ \\
\hline 12 & $\begin{array}{l}\text { Salamat et al. [16], } \\
2004\end{array}$ & Fourth & $\begin{array}{l}\text { CS in 8th month of pregnancy; intrauterine death due to } \\
\text { fetal hydrops }\end{array}$ & No & \\
\hline 13 & $\begin{array}{l}\text { Hirose et al. [17], } \\
2004\end{array}$ & $\begin{array}{l}\text { First; blood } \\
\text { transfusion } \\
\text { before } \\
\text { pregnancy }\end{array}$ & $\begin{array}{l}\text { CS in 34th week, severe anemia and hyperbilirubinemia; } \\
\text { after therapy the infant is alive and in good health }\end{array}$ & $1 \mathrm{IUT}, 2 \mathrm{ET}$ & $\begin{array}{l}\text { Compatible fresh } \\
\text { donor's RBCs }\end{array}$ \\
\hline 14 & Shah et al. [18], 2005 & Fourth & $\begin{array}{l}\text { Delivery in 37th week; after therapy baby is alive and in } \\
\text { good health }\end{array}$ & $\begin{array}{l}3 \text { ET, } 1 \text { TUT, } \\
\text { IVIG }\end{array}$ & $\begin{array}{l}\text { Maternal RBCs } \\
\text { (1 ET, } 1 \text { TUT); } \\
\text { incompatible } \\
\text { RBCs (2 ET) }\end{array}$ \\
\hline
\end{tabular}


Table 2 (continued)

\begin{tabular}{|c|c|c|c|c|c|}
\hline Case & $\begin{array}{l}\text { Authors [reference], } \\
\text { year of publication }\end{array}$ & $\begin{array}{l}\text { Order of } \\
\text { pregnancies }\end{array}$ & HDFN and outcome & $\begin{array}{l}\text { Transfusion } \\
\text { therapy and } \\
\text { other manage- } \\
\text { ment of HDFN }\end{array}$ & $\begin{array}{l}\text { Source of RBC for } \\
\text { fetal and neonatal } \\
\text { transfusion }\end{array}$ \\
\hline 15 & Li et al. [26], 2010 & Second & $\begin{array}{l}\text { Delivery 39th week; neonatal anemia }(\mathrm{Hb} 8.1 \mathrm{~g} / \mathrm{dL}) \text {, } \\
\text { severe hyperbilirubinemia and neonatal hydrops; after } \\
\text { therapy the infant is alive and in good health }\end{array}$ & $\begin{array}{l}1 \mathrm{ET}, 3 \text { TUT, } \\
\text { IVIG, photo- } \\
\text { therapy, methyl- } \\
\text { prednisolone }\end{array}$ & $\begin{array}{l}\text { Incompatible } \\
\text { RBCs, donors O } \\
\text { RhD-positive } \\
\text { phenotype ccEE }\end{array}$ \\
\hline
\end{tabular}

HDFN, hemolytic disease of the fetus and newborn; Hb, hemoglobin; IUT, intrauterine transfusion; ET, exchange transfusion; TUT, top-up transfusion; IVIG, intravenous immunoglobulin; CS, cesarean section.

observations that alloimmunization caused by anti-Rh17 antibodies have malignant potential for HDFN, even more severe than those triggered by anti-D, $-\mathrm{K}$, and $-\mathrm{C}$ antibodies.

\section{Relationship of Antibody and Previous Pregnancies and Transfusion}

Out of 18 women described with anti-Rh17 (15 cases from the available literature and 3 in this study), 2 women were immunized by blood transfusions [17], in 3 women, pregnancy or transfusion probably were the triggers of immunization $[10,15,16]$, and $13(72 \%)$ of them were immunized exclusively by pregnancies. Comparing with other non-RhD antibodies that are associated with maternal transfusion in about $50 \%$ of pregnancies, Rh17 immunization is mostly caused by previous pregnancies.

Most of the authors recommend that transfusion therapy in women younger than 50 years of age should be $\mathrm{K}$, Rhc-, and RhE- compatible [19, 20]. In our presented Case 1, D-- phenotype was not tested before transfusion. Consequently, following the transfusion of random $\mathrm{RhD}+\mathrm{RBC}$ concentrates, this pregnant woman developed a strong immune response and intrauterine death of the fetus due to HDFN. This is the first reported case of intrauterine death only 3.5 months after antibody screening was negative. We can assume that such strong reaction may occur when the $\mathrm{RhD}$-negative pregnant mother is transfused $\mathrm{RhD}$-positive blood during pregnancy, since the protein of $\mathrm{C} / \mathrm{c}, \mathrm{E} / \mathrm{e}$ antigens have the same feature as the RhD antigen. Although fatal HDFN in this case was caused by rare anti-Rh17 antibodies, one should keep in mind that transfusions during pregnancy should be performed with extreme caution as the strong immune reaction and severe HDFN may occur not only in subsequent, but also in the current pregnancy (our Case 1, third pregnancy). Therefore, we suggest repeating the antibody screening test for 6-8 weeks after RBC transfusions during pregnancy in cases with an initial negative result of screening for RBC antibodies. Also, we suggest repeating antibody screening for women with known D-- phenotype during the 28th-30th week be- cause of anti-Rh17 immunization risk and its destructive features (Fig. 1).

Regarding RBC alloimmunization by transfusion, it is advisable that all women of childbearing age are given $\mathrm{RBCs}$ compatible with Rh and Kell phenotype to prevent Rhc, Kell, RhE, RhC, and Rh17 immunizations $[19,20]$.

\section{Current Strategies in Diagnosis and Treatment of}

Fetal Anemia for High-Risk Pregnant Women

The revolutionary change in the diagnosis and treatment of fetal anemia occurred almost two decades ago after Mari et al. [21] published a study showing that fetal middle cerebral artery peak systolic velocity (MCA-PSV) is an excellent tool for the diagnosis of fetal anemia. Briefly, if a fetus is deemed at significant risk for severe fetal anemia (MCA greater than 1.5 multiples of the median or hydropic), fetal blood sampling should be performed with preparation for an IUT, unless the pregnancy is at a gestational age when the risks associated with delivery are considered to be less than those associated with the procedure. MCA-PSV measurement, as noninvasive diagnostic procedure, has completely replaced invasive amniocentesis and bilirubin measurement as surrogate for the degree of fetal anemia. Fetal MCA Doppler may also be used for the determination of subsequent IUTs. The study of Martínez-Portilla et al. [22] provided further evidence that MCA-PSV $\geq 1.5$ multiples of the median is a moderate predictor of moderate-severe anemia in untransfused fetuses, but its accuracy significantly declines with an increasing number of IUTs.

IUT at gestational age remote from term is a very challenging procedure, especially before 20 weeks. Intravenous immunoglobulin treatment in mothers pregnant with a fetus at risk for hemolytic disease seems to have a potential clinically relevant beneficial effect on the course and severity of the disease by postponing the first IUT up to 25 days if the treatment is commenced weekly at the end of the first trimester [23]. This research included exclusively pregnancies complicated by anti-D and anti-Kell alloimmunization. Therapeutic plasma exchange, alone or in combination with immu- 


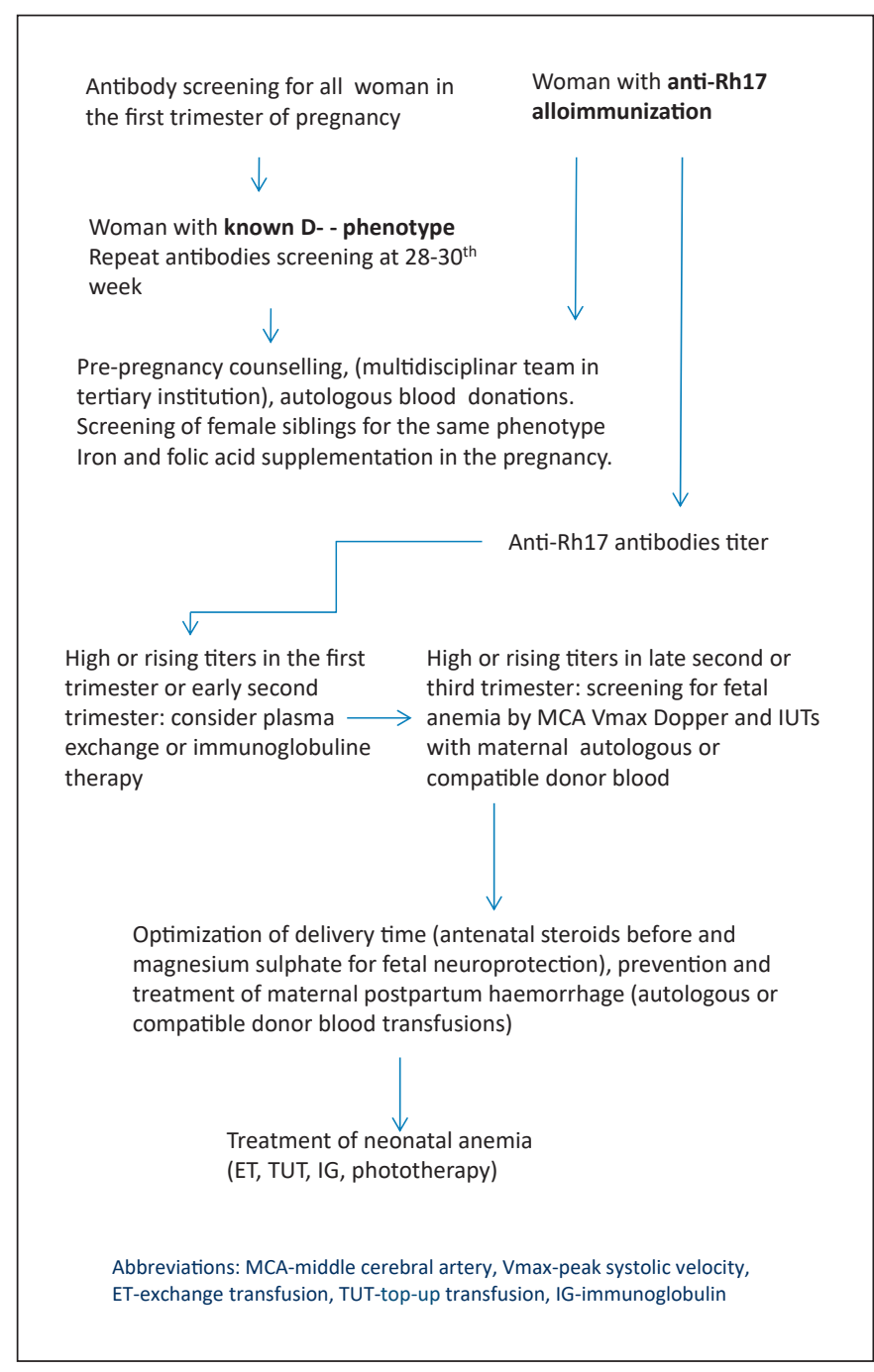

Fig. 1. Proposed simplified flowchart for the planning and management of pregnancy in women with $\mathrm{D}$-- phenotype and antiRh17 alloimmunization.

noglobulin, to prevent or alleviate alloantibodies or to postpone the first IUT has been reported as an option in such pregnancies [24].

However, there are no international guidelines on the time of commencement of therapy, interval of treatments, and its duration, and the experience is based on case reports and small case series. A simplified flowchart for the management of pregnant women of phenotype D-- and management of severe HDFN is displayed in Figure 1.

\section{Transfusion Therapy of Anti-Rh17 HDFN}

Severe cases of HDFN require transfusion antenatal of postnatal management, but in case of antibodies to highfrequency antigens, this is always a considerably challenging. Various approaches to transfusion therapy in HDFN caused by anti-Rh17 antibodies have been proposed. In cases when HDFN management is planned well in advance, the options for transfusions are as follows:
- Donations of maternal blood. According to the existing data, IUTs are most commonly performed with the donated maternal blood in such cases $[10,12,15,18]$. Washed and irradiated mother RBCs are a reasonable choice because small amounts of donated blood needed for IUT possess no risk for the mother and are sufficient for the fetus. However, when multiple maternal blood donations for IUT are needed, it is necessary to advise iron and folic acid supplementation. Serial maternal donations can be successfully managed by recombinant human erythropoietin and intravenous iron [25]. Washed maternal RBCs are safe for fetal transfusion therapy, even when they are $\mathrm{ABO}$ incompatible, because the fetus does not have its own anti-A and anti-B antibodies, so maternal RBCs cannot be hemolyzed [15]. Maternal blood may be the best option for ET if she can tolerate blood donation and her RBCs are $\mathrm{ABO}$ compatible with the cord blood.

- In some cases, relatives of the pregnant woman, most often D-- siblings, or donors with the same Rh phenotype have been donating fresh blood $[10,17]$ as in our Case 2, where blood for IUT and ET was from a D-donor.

- In certain cases, the woman may donate RBCs prior to pregnancy. In such cases, RBCs should be frozen and after delivery prepared for ET and top-up transfusions [12].

- Few cases using thawed phenotype D-- units from the Frozen Blood Bank have been reported $[8,14]$.

Two cases were described when transfusion therapy was necessary and RBC with phenotype D-- were not available $[5,6]$. Such situations usually occur when immunization is not known prior to delivery. The mother could not donate blood due to profound anemia. Therefore, transfusion therapy was delayed because of the lack of compatible blood. The consequences in these cases were fatal. In the first case, a newborn infant was born with severe and worsening hyperbilirubinemia with consequent hydrops on the fourth postnatal day. ET was again performed with maternal blood. Despite this, the outcome was fatal [5]. In the second case, the pregnant woman delivered four healthy children without HDFN, but in the fifth and sixth pregnancy, there was severe HDFN. The ETs were made in both cases with maternal blood. However, the outcome was also fatal in this case, as well [6].

On the other hand, five cases with transfusion therapy that was necessary and where RBCs of D-- phenotype were not available have been reported. Emergency ETs, shown in the presented cases, were performed with incompatible RBCs [7, 9, 15, 18, 26]. Only one presented case had fatal outcome, but the newborn died due to hydrops and cardiac failure $29 \mathrm{~h}$ after birth [9]. In the other cases described, incompatible transfusions had a pos- 
itive outcome and the children were well recovered. In our Case 3, ETs and top-up transfusions were done also with incompatible RBCs. An explanation of the positive outcome, after incompatible ETs, is elimination of bilirubin, removal of RBC-coated antibodies, increase of hemoglobin level, and removal of maternal antibodies from the newborn's circulation. However, ET cannot remove the bulk of antibody from other body fluids except blood, which can reenter the blood and cause relapse of anemia. Nevertheless, there will be considerably fewer antibodies than before ET. In some cases with incompatible ETs and top-up transfusions, corticosteroids and intravenous immunoglobulin were used, with the aim to alleviate hemolytic reaction and to extend survival of transfused erythrocytes $[18,26]$. Among the described cases of HDFN treated with incompatible transfusion, there was not a single case of incompatible top-up transfusion which did not require ET $[7,9,15,18,26]$. Therefore, we suggest that the cases of HDFN which require only top-up transfusion, but not ET, should be treated with compatible or phenotype D-- RBCs because of the risk of hyperbilirubinemia.

On the other hand, several adult patients with highfrequency alloantibodies or multiple antibodies in lifethreatening conditions who received transfusions with incompatible RBC have been reported. Non-ABO antibodies typically, though not exclusively, cause delayed extravascular red cell destruction which is less severe than $\mathrm{ABO}$ hemolysis and if incompatible $\mathrm{RBCs}$ have been transfused, the potential adverse effects can be minimized. For the prevention and alleviation of hemolytic transfusion reactions, therapy with intravenous immunoglobulins and steroids was included in such cases [2729]. In the case of elective surgery, more options are described, e.g., iron therapy and preoperative donations, using intraoperative cell salvage, and autologous or allogeneic units from the Frozen Blood Bank [30].

The strength of this study is the identification and critical evaluation of all published cases of the rare HDFN caused by anti-Rh17 antibodies and the development of a simplified flowchart for the planning and management of such pregnancies.
One of the limitations is that we were not able to provide all relevant data (i.e., exact blood volume for IUTs and ETs) in certain women of our case series due to the fact that they were managed in two institutions during 18 years. Regrettably, we did not determine precise molecular features of RHCE genes and subclasses of anti-Rh17 antibodies in our patients.

In conclusion, anti-Rh17 antibodies cause extremely severe HDFN and despite the extremely malignant antibody features, incompatible ETs have a favorable outcome. In this study, we did not analyze the transfusion treatment when HDFN is caused by other antibodies to high-frequency antigens or is caused by multiple antibodies. Given the favorable outcomes caused by anti-Rh17 antibodies, we suggest that in case of severe HDFN caused by these antibodies, emergency ETs with incompatible RBC will have favorable outcomes.

Based on the available literature and reported own cases, we conclude that in cases of antibodies to high-frequency antigens such as anti-Rh17, different approaches to HDFN transfusion therapy are available. In emergencies, when there is no compatible blood and maternal is not available, incompatible ETs are better choices than ET delay when needed.

Apart from the need for increased awareness, it is of essential importance that pregnancies with high risk of HDFN due to anti-Rh17 are managed by a multidisciplinary team (transfusion medicine specialist, obstetrician, neonatologist) in a highly specialized tertiary institution. We also propose the establishment of an international registry that includes all cases of HDFN caused by rare anti-Rh17 antibodies.

\section{Statement of Ethics}

All three women whose pregnancies we have presented have given their written informed consent to publish their cases.

\section{Disclosure Statement}

The authors have no conflicts of interest to declare.

\section{References}

1 Klein H, Anstee D. The Rh blood group system (and LW). In: Klein H, Anstee D, editors. Mollison's Blood Transfusion in Clinical Medicine. 11th ed. London: Blackwell Science; 2005. pp. 163-208.

2 Race RR, Sanger R, Selwyn JG. A probable deletion in a human $\mathrm{Rh}$ chromosome. Nature. 1950 Sep;166(4221):520.

3 Huang $\mathrm{CH}$, Reid ME, Chen Y. Identification of a partial internal deletion in the $\mathrm{RH}$ locus causing the human erythrocyte D-- phenotype. Blood. 1995 Jul 15;86(2):784-90.
4 Daniels G. Rh and RhAG blood group system. Human blood groups. Daniels G. 2nd ed. Oxford: Blackwell Science; 2005. pp. 182258.

5 De Torregrosa MV, Rullan MM, Cecile C, Sabater A, Alberto C. Severe erythroblastosis in a primigravida associated with absence of $\mathrm{Rh}$ chromosomes. Am J Obstet Gynecol. 1961 Dec;82(6):1375-8.

6 Badakere S, Bhatia H. Haemolytic disease of the newborn in a D-/D- Indian woman. Vox Sang. 1973;24(3):280-2.
7 Diao Y, Song N, Guan Z, Zhang L, Wang Y, Wan M. A case of hemolytic disease of the newborn caused by anti-Hro and anti-e. Proc Chin Acad Med Sci Peking Union Med Coll. 1990;5(1):58-60.

8 Mertens G, Muylle L, Ursi JP, Docx M, Renard JM. Transfusion with thawed Rh- D blood of a newborn suffering from haemolytic disease due to anti-Rh 17. J Obstet Gynaecol. 1997 Nov;17(6):590-1. 
9 Han KS, Kim HC, Han KS, Shim WS. A case of fatal hemolytic disease of the newborn associated with-D-/-D-phenotype. Am J Perinatol. 1997 Sep;14(8):495-7.

10 Whang DH, Kim HC, Hur M, Choi JH, Park JS, Han KS. A successful delivery of a baby from a D-/D- mother with strong anti-Hr0. Immunohematology. 2000;16(3):112-4.

11 Lenkiewicz B, Zupanska B. Moderate hemolytic disease of the newborn due to anti-Hr0 in a mother with the D-/D- phenotype. Immunohematology. 2000;16(3):109-11.

12 Deitenbeck R, Tutschek B, Crombach G Stannigel H. Successful management of pregnancy and hemolytic disease of the newborn due to anti-HrO in a woman of the D-- phenotype. Transfusion. 1999 Oct;39(10):11512.

13 Brumit MC, Carnahan GE, Stubbs JR, Storry JR, Reid ME. Moderate hemolytic disease of the newborn (HDN) due to anti-Rh17 produced by a black female with an e variant phenotype. Immunohematology. 2002;18(2):40

14 Aref K, Boctor FN, Pande S, Uehlinger J, Manning F, Eglowstein M, et al. Successful perinatal management of hydrops fetalis due to hemolytic disease associated with D-- maternal phenotype. J Perinatol. 2002 Dec;22(8): 667-8.

15 Denomme GA, Ryan G, Seaward PG, Kelly EN, Fernandes BJ. Maternal ABO-mismatched blood for intrauterine transfusion of severe hemolytic disease of the newborn due to anti-Rh17. Transfusion. 2004 Sep;44(9): 1357-60.

16 Salamat N, Bhatti FA, Hussain A, Ziaullah. Anti-Rh17 (anti-Hr0): a rare diagnostic and management problem. J Pak Med Assoc. 2004 Apr;54(4):215-8.
17 Hirose M, Nakanishi K, Kaku S, Moro H, Hodohara K, Aotani $\mathrm{H}$, et al. Fetal hemolytic disease due to anti-Rh17 alloimmunization. Fetal Diagn Ther. 2004 Mar-Apr;19(2):182-6.

18 Shah SI, Caprio M, Strauss R, Moskowitz N. Management of a full-term infant with hemolytic disease of the newborn due to an antiRh17 antibody in a mother with D-- phenotype. Am J Hematol. 2005 Sep;80(1):88-9.

19 Dajak S, Culić S, Stefanović V, Lukačević J. Relationship between previous maternal transfusions and haemolytic disease of the foetus and newborn mediated by non-RhD antibodies. Blood Transfus. 2013 Oct;11(4): 528-32.

20 Koelewijn JM, Vrijkotte TG, de Haas M, van der Schoot CE, Bonsel GJ. Risk factors for the presence of non-rhesus D red blood cell antibodies in pregnancy. BJOG. 2009 Apr;116(5): 655-64.

21 Mari G, Deter RL, Carpenter RL, Rahman F, Zimmerman R, Moise KJ Jr, et al.; Collaborative Group for Doppler Assessment of the Blood Velocity in Anemic Fetuses. Noninvasive diagnosis by Doppler ultrasonography of fetal anemia due to maternal red-cell alloimmunization. N Engl J Med. 2000 Jan;342(1): 9-14.

22 Martínez-Portilla RJ, Lopez-Felix J, HawkinsVillareal A, Villafan-Bernal JR, Paz Y Miño F, Figueras F, et al. Performance of middle cerebral artery peak systolic velocity for the prediction of fetal anemia in untransfused and transfused fetuses: a diagnostic test accuracy meta-analysis. Ultrasound Obstet Gynecol. 2019 Apr 1. DOI: 10.1002/uog.20273.

23 Zwiers C, van der Bom JG, van Kamp IL, van Geloven N, Lopriore E, Smoleniec J, et al. Postponing Early intrauterine Transfusion with Intravenous immunoglobulin Treatment; the PETIT study on severe hemolytic disease of the fetus and newborn. Am J Obstet Gynecol. 2018 Sep;219(3):291.e1-9.
24 Nwogu LC, Moise KJ Jr, Klein KL, Tint H, Castillo B, Bai Y. Successful management of severe red blood cell alloimmunization in pregnancy with a combination of therapeutic plasma exchange, intravenous immune globulin, and intrauterine transfusion. Transfusion. 2018 Mar;58(3):677-84.

25 Al Riyami AZ, Al Salmani M, Al Hashami S, Al Mahrooqi S, Al Hinai S, Al Balushi H, et al. Successful management of severe hemolytic disease of the fetus due to anti-Jsb using intrauterine transfusions with serial maternal blood donations: a case report and a review of the literature. Transfusion. 2014 Jan;54(1): 238-43.

26 Li BJ, Jiang YJ, Yuan F, Ye HX. Exchange transfusion of least incompatible blood for severe hemolytic disease of the newborn due to anti-Rh17. Transfus Med. 2010 Feb;20(1):669.

27 Kohan AI, Niborski RC, Rey JA, Amerise G, Vázquez MI, Zani N, et al. High-dose intravenous immunoglobulin in non-ABO transfusion incompatibility. Vox Sang. 1994;67(2): 195-8.

28 Woodcock BE, Walker S, Adams K. Haemolytic transfusion reaction - successful attenuation with methylprednisolone and high dose immunoglobulin. Clin Lab Haematol. 1993; 15(1):59-61.

29 Win N, Needs M, Thornton N, Webster R, Chang C. Transfusions of least-incompatible blood with intravenous immunoglobulin plus steroids cover in two patients with rare antibody. Transfusion. 2018 Jul;58(7):1626-30.

30 De Vooght KM, Demir AY, Folman CC, Schutgens RE, van Solinge WW, Kemperman H. Successful transfusion care for a patient with the Rhesus -D- phenotype and antibodies against Rh17 and two additional alloantibodies. Ann Hematol. 2012 Jun;91(6):963-4. 